\title{
Kinetic and modeling of radiolytic decomposition of antibiotics
}

\author{
S. Yu, D. Choi \& M. Lee \\ Advanced Radiation Technology Institute, \\ Korea Atomic Energy Research Institute, Korea
}

\begin{abstract}
There has been recent growing interest in the presence of antibiotics in different environmental compartments. One considerable concern is the potential development of antibiotic-resistant bacteria in the environment, even at low concentrations. Kinetic experiments were conducted to compare two kinetic models for radiolytic decomposition of various antibiotics such as cephradine, amoxicillin, sulfamethazine, tetracycline, and lincomycin. Batch kinetic experiments with initial aqueous concentrations of 2, 6, 8, 20 mg/L showed the decomposition of antibiotics using gamma radiation followed a pseudo first-order reaction, and the dose constant increased with lower initial concentrations. For comparison of a kinetic model for radiolytic decomposition of various antibiotics, the Monod equation was used. The kinetic parameters of maximum reaction rates $\left(k_{\max }\right)$ and half-velocity coefficient $\left(\mathrm{K}_{\mathrm{s}}\right)$ are obtained. The $k_{\max }$ values ranged from 0.29 to $0.99 \mu \mathrm{M} / \mathrm{Gy}$. The $\mathrm{K}_{\mathrm{s}}$ values for antibiotics decreased in the order of: cephradine $>$ lincomycin $>$ amoxicillin $>$ sulfamethazine $>$ tetracycline. Radiolytic decomposition of antibiotics by gamma radiation was well described by both a pseudo first-order reaction and the Monod equation.
\end{abstract}

Keywords: radiation, antibiotics, kinetics, modeling.

\section{Introduction}

Reports in the literature show that pharmaceuticals used in human and animal husbandry are present in soil, sediment, surface water, and groundwater. As important pharmaceuticals in today's medicine, antibiotics are used mainly to prevent and treat human and animal diseases, as well as for growth promoters in 
the intensive farming system. The antibiotics can be introduced to the various environments as parent compounds or metabolites by an excretion, disposal of unused or expired drugs, and accidental spills [1-3]. These antibiotics are incompletely degraded by the biological processes, and ultimately detected from $\mu \mathrm{g} / \mathrm{L}$ to $\mathrm{ng} / \mathrm{L}$ in aquatic environments [4-7]. The continual exposure to antibiotics, even at low concentration, may lead to developing antibioticresistance genes in bacterial strains and unknown adverse effects on humans and the ecosystem such as genotoxic potentials and disruption of the aquatic ecosystem [1,7-10].

Recently, many researches have been conducted on the treatment of antibiotics found in groundwater, surface water, and wastewater. Ingerslev et al. [11] showed that antibiotics under aerobic and anaerobic conditions were not readily biodegradable. Advanced oxidation processes (AOPs) have been suggested in recent years as a suitable alternative for the removal of refractory organic compounds found in a variety of environments. AOPs by using free radicals such as the hydroxyl radical $(\mathrm{OH})$ include ozone, ozone/UV, $\mathrm{TiO}_{2}$ photo catalysis, Fenton's reaction, $\mathrm{H}_{2} \mathrm{O}_{2} / \mathrm{UV}, \mathrm{H}_{2} \mathrm{O}_{2} / \mathrm{O}_{3}$ and ionizing radiation $[4,12,13]$. Ozone is a strong oxidant and disinfectant for drinking water and industrial wastewater, and can be effectively used as a pretreatment process to improve the biological degradation efficiency of wastewater containing antibiotics $[4,14,15]$. Abellan et al. [15] recently reported that $82 \%$ of sulfamethoxazole degradation efficiency was obtained with UV and $\mathrm{TiO}_{2}$ as a catalyst.

Among these AOPs, ionizing radiation has promise as a removal process of the toxic organic pollutants. In water radiolysis, the primary species $\left(\mathrm{OH}, \mathrm{e}_{\mathrm{aq}}{ }^{-}\right.$, and $\mathrm{H})$ and molecular products $\left(\mathrm{H}_{2}, \mathrm{H}_{2} \mathrm{O}_{2}\right)$ are generated by the following equation [16]:

$$
\mathrm{H}_{2} \mathrm{O} \sim>\cdot \mathrm{OH}+\mathrm{H} \cdot+\mathrm{e}_{\mathrm{aq}}^{-}+\mathrm{H}_{2}+\mathrm{H}_{2} \mathrm{O}_{2}+\mathrm{H}_{3} \mathrm{O}^{+}
$$

These reactive species/radicals react with target compounds for decomposition of solutes present in water. There have been a number of studies examining the radiolytic decomposition of the refractory organic compounds such as nitrobenzene, diazinon pesticide, methyl tert-butyl ether (MTBE), polychlorinated biphenyl (PCB), and trinitrotoluene (TNT) [17-22]. Yu et al. [23] also showed that $30 \mathrm{mg} / \mathrm{L}$ of cefaclor was completely degraded after $1 \mathrm{kGy}$ by gamma radiation. However, it is very difficult to compare the radiolytic removal efficiencies for various toxic organic chemicals due to the use of different kinetic figures-of-merit. The development of the most reliable kinetic models and figure-of-merit will be useful to predict the irradiation dose requirement and obtain an optimization in an irradiation system.

This study focused on the evaluation of the kinetic parameters of different degradation models for the radiolytic decomposition of different groups of antibiotics. Among many kinds of antibiotics, the target antibiotics studied were: $\beta$-lactams (penicillins: amoxicillin and cephalosporins: cephradine); non $\beta$ lactams (tetracyclines: tetracycline, sulfonamide: sulfamethazine and lincosamides: lincomycin). The selected chemicals represent the most important antibiotics used in human and animal. The objectives of this study were: 1) to 
investigate the removal of the five antibiotics in aqueous solution by gamma irradiation; and 2) to compare the decomposition kinetics of the antibiotics by the three figures-of-merit (dose constant and the Monod equation parameters $\left(k_{\max }\right.$ and $\left.\mathrm{K}_{\mathrm{s}}\right)$ ).

\section{Materials and method}

\subsection{Chemicals}

Amoxicillin, cephradine, tetracycline, lincomycin and sulfamethazine were obtained from Sigma-Aldrich, Co. (St Louis, MO, USA) with a purity higher than $99 \%$. The chemical structures of the antibiotics used in this study are shown in Figure 1. All chemicals used for HPLC analysis were of HPLC grade and purchased from Sigma-Aldrich, Co. (St Louis, MO, USA), J.T. Baker (USA) and Kanto Chemical Co., Inc. (Japan). All solutions were prepared with Milli-Q purified water (Millipore).

\subsection{Irradiation sources}

Gamma irradiations were performed with a high-level ${ }^{60} \mathrm{CO}$ source (Nordion Inc., Canada) at the Korea Atomic Energy Research Institute (Jeongup, Korea). The radioactivity of the source was around 1.47 X $10^{17} \mathrm{~Bq}$ (= $397949 \mathrm{Ci}$ ). Aqueous antibiotics solutions were irradiated in $50 \mathrm{~mL}$ screw cap bottles and 2 $\mathrm{mL}$ septa-capped vial without any headspace. The solutions were prepared 24 hrs prior to irradiation and stored at $4^{\circ} \mathrm{C}$. All the samples were prepared in equilibrium with an atmospheric pressure and room temperature $\left(22^{\circ} \mathrm{C} \pm 2\right)$ before irradiated, and were sealed with screw caps to avoid the contact with air.

Table 1: Column information of high performance liquid chromatography used in the analysis of antibiotics.

\begin{tabular}{|c|c|c|c|c|c|}
\hline & $\begin{array}{c}\text { Column } \\
\text { stationary phase }\end{array}$ & $\begin{array}{c}\text { Injection } \\
\text { volume }(\mu l)\end{array}$ & $\begin{array}{l}\text { Flow rate } \\
(\mathrm{mL} / \mathrm{min})\end{array}$ & $\begin{array}{l}\text { UV wave } \\
\text { length } \\
(\mathrm{nm})\end{array}$ & Eluent \\
\hline Amoxicillin & $\mathrm{C}^{\mathrm{a}}$ & 50 & 1.0 & 230 & $\begin{array}{c}25 \mathrm{mM} \text { Potassium phosphate } \mathrm{pH} 4.6 \\
: \text { Methanol } \\
(95: 5)\end{array}$ \\
\hline Cephradine & Polar $\mathrm{RP}^{\mathrm{b}}$ & 50 & 1.0 & 254 & $\begin{array}{l}20 \mathrm{mM} \text { Ammonium formate } \mathrm{pH} 3.5 \text { : } \\
\text { Methanol } \\
(65: 35)\end{array}$ \\
\hline Sulfamethazine & $\mathrm{C} 18^{\mathrm{c}}$ & 50 & 0.6 & 254 & $\begin{array}{c}0.1 \% \text { Formic acid in water : } 0.1 \% \\
\text { Formic acid in Acetonitrile } \\
(70: 30)\end{array}$ \\
\hline Tetracycline & $\mathrm{C} 8^{\mathrm{a}}$ & 50 & 1.0 & 355 & $\begin{array}{l}\text { 0.01 M Oxalic acid : Methanol : } \\
\text { Acetonitrile } \\
(72: 8: 20)\end{array}$ \\
\hline Lincomycin & $\mathrm{C} 18^{\mathrm{d}}$ & 75 & 0.7 & 210 & $\begin{array}{c}1 \mathrm{mM} \text { Ammonium formate : } \\
\text { Acetonitrile } \\
(65: 35)\end{array}$ \\
\hline
\end{tabular}

${ }^{\mathrm{a}}$ Luna $5 \mu$ C8(2) 100A $150 \times 4.6 \mathrm{~mm}$ (Phenomenex, Torrance, CA, USA).

${ }^{\mathrm{b}}$ Synergi $4 \mu$ Polar-RP column $150 \times 4.6 \mathrm{~mm}$ (Phenomenex, Torrance, CA, USA)).

${ }^{\mathrm{c} O n y x}$ Monolithic C18 $100 \times 3.0 \mathrm{~mm}$ (Phenomenex, Torrance, CA, USA)).

${ }^{\mathrm{d}}$ Zorbax sb-C18 $250 \times 3.0 \mathrm{~mm}$ (Agilent Technologies, Santa Clara, CA, USA). 


\subsection{Analytical methods}

Antibiotics concentrations in the aqueous samples were measured using high performance liquid chromatography (HPLC) using an Agilent 1200 Series HPLC (Agilent Technologies, Santa Clara, CA, USA), equipped with an UV absorbance detector. The operation conditions of HPLC measurement are listed in Table 1. Triplicate samples for all experiments were analyzed for the reproducibility.

\section{Results and discussion}

\subsection{Radiolytic decomposition of antibiotics}

A typical decomposition curve of antibiotics by gamma radiation is shown in Figure 1. Experiments were conducted in quintuplicate to ensure that the kinetic results were reproducible for each dose amount tested. The aqueous concentrations of antibiotics irradiated were all $30 \mathrm{mg} / \mathrm{L}$ in batch bottles without a head space (total volume $=150 \mathrm{~mL}$ ). The irradiation doses were up to $4 \mathrm{kGy}$. As shown in Figure 1, the decomposition extent of antibiotics increased as the absorbed dose increased. Most of the antibiotics of $30 \mathrm{mg} / \mathrm{L}$ were completely degraded after $1 \mathrm{kGy}$, but sulfamthazine needed $4 \mathrm{kGy}$ for the complete decomposition.

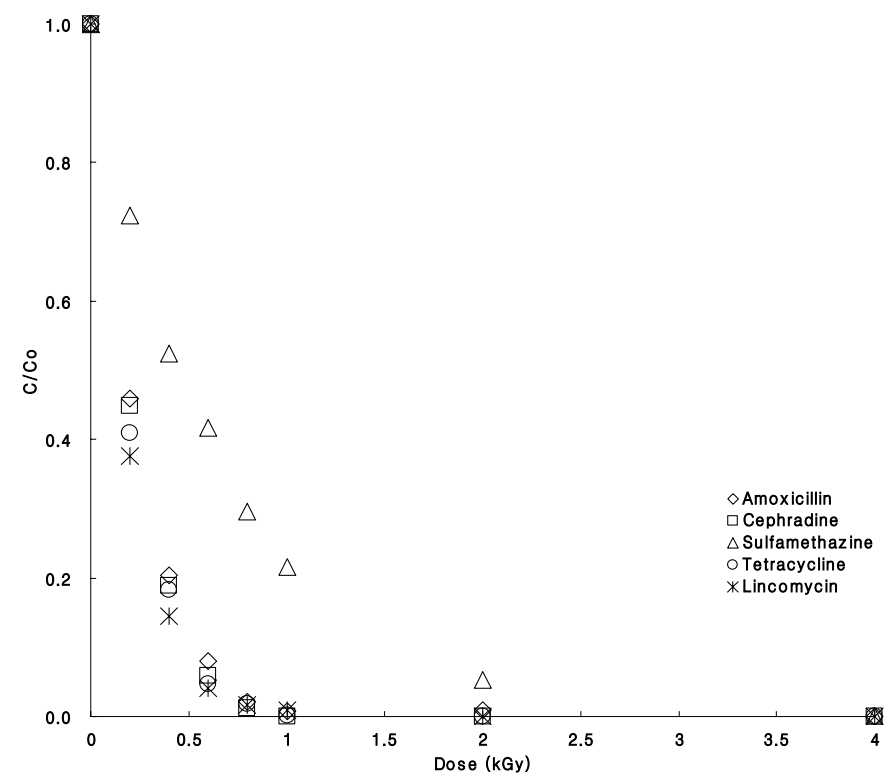

Figure 1: Radiolytic decomposition of antibiotics of $30 \mathrm{mg} / \mathrm{L}$ by gamma radiation. 


\subsection{Determination of chemical reaction constants for radiolytic decomposition of antibiotics}

Most radiolytic degradations of organic compounds are represented by equation (2), which has been used to describe dose-dependant degradation rates [22, 24]

$$
C=C_{0} e^{-d D}
$$

where $C$ is the aqueous concentration of antibiotics, $d$ the dose constant in reciprocal dose units, and $D$ the absorbed dose.

Batch kinetic experiments were performed to study the initial aqueous concentration dependency on antibiotics decomposition by gamma radiation. Initial aqueous concentrations of antibiotics ranged from 2 to $50 \mathrm{mg} / \mathrm{L}$ and the absorbed doses from 0 to $120 \mathrm{~Gy}$. All of the kinetic experiments were performed at the ambient temperature and atmospheric conditions.
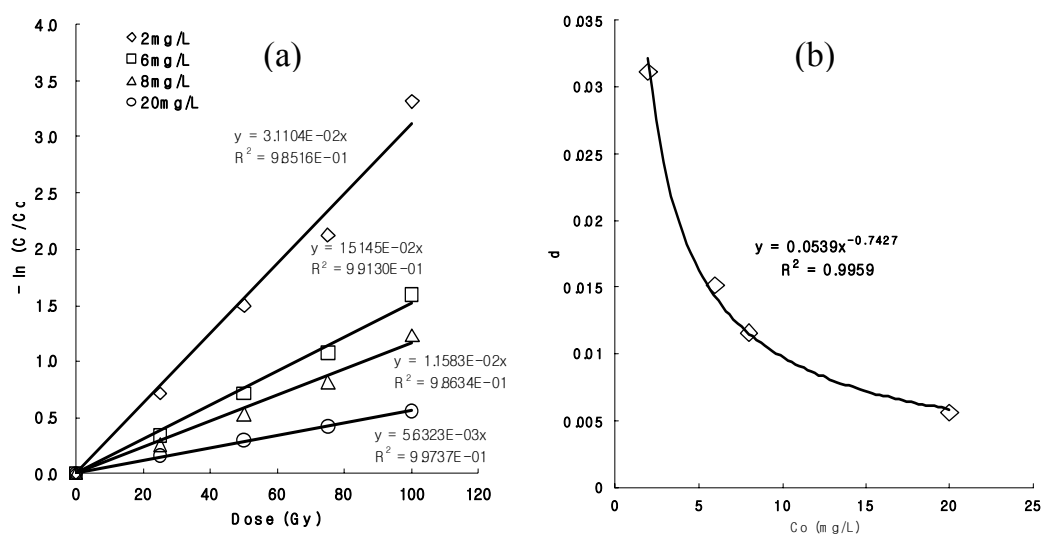

Figure 2: Kinetic results of radiolytic decomposition of cephradine at different initial aqueous concentrations: initial concentration dependency on dose constants.

Table 2: $\quad$ Dose constants of antibiotics.

\begin{tabular}{ccc}
\hline Antibiotics & Dose constant $(\mathrm{d})\left(\mathrm{Gy}^{-1}\right)$ & $\mathrm{R}^{2}$ \\
\hline Cephradine & $0.0539 \mathrm{Co}^{-0.7427}$ & 0.9959 \\
Amoxicillin & $0.0633 \mathrm{Co}^{-0.8602}$ & 0.9996 \\
Sulfamethazine & $0.0541 \mathrm{Co}^{-0.8983}$ & 0.987 \\
Tetracycline & $0.1772 \mathrm{Co}^{-0.853}$ & 0.9783 \\
Lincomycin & $0.0515 \mathrm{Co}^{-0.7244}$ & 0.9908 \\
\hline
\end{tabular}


Figure 2 shows the results of a radiolytic decomposition of cephradine at different initial aqueous concentrations. The kinetic experiments were performed in duplicate, which revealed near identical results. All of the experimental data (Figure2) was fit to the pseudo first-order reaction model, which showed statistically reliable results $\left(\mathrm{R}^{2}\right.$ values higher than 0.985$)$. The dose constants of five antibiotics at different initial concentrations are listed in Table 2 .

\subsection{Determination of kinetic parameters of the Monod equation}

The radiation dose-dependent kinetics of removal reaction of the antibiotics were investigated by the measurement of the radiolytic degradation rates at different initial concentrations of the antibiotics. The radiolytic decomposition of a given antibiotic can be described using the Monod equation (equation 3), frequently used in enzyme kinetic studies [25, 26, 27, 28, 29, 30].

$$
r=\frac{k_{\max } \times \mathrm{S}}{\mathrm{K}_{\mathrm{s}}+\mathrm{S}}
$$

Where $r$ is the removal rate $(\mu \mathrm{M} / \mathrm{Gy})$ of the antibiotics concentration, $k_{\max }$ maximum specific reaction rate $(\mu \mathrm{M} / \mathrm{Gy}), \mathrm{K}_{\mathrm{s}}$ half-velocity coefficient $(\mu \mathrm{M})$ and $\mathrm{S}$ the aqueous concentration of antibiotics $(\mu \mathrm{M})$.

Figure 3 shows the Monod equation curve of radiolytic decomposition of cephradine. Table 3 presents the $k_{\max }$ and $\mathrm{K}_{\mathrm{s}}$ values obtained by fitting the experimental data. The highest $k_{\max }$ value was $0.99 \mu \mathrm{M} / \mathrm{Gy}$ of cephradine and the lowest $\mathrm{K}_{\mathrm{s}} 1.49 \mu \mathrm{M}$ of tetracycline, indicating that tetracycline is rapidly decomposed at lower concentrations while cephradine at higher concentrations.

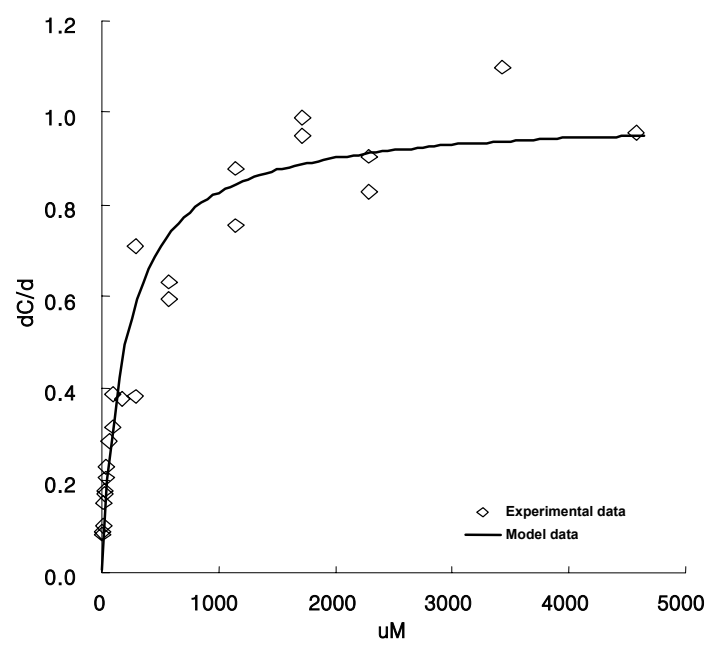

Figure 3: Initial degradation rates of cephradine by gamma radiation. 
Table 3: Kinetic parameters of the Monod equation for radiolytic decomposition of five antibiotics in aqueous solution.

\begin{tabular}{ccc}
\hline Antibiotics & $\boldsymbol{k}_{\boldsymbol{m a x}}(\mu \mathrm{M} / \mathrm{Gy})$ & $\mathbf{K}_{\mathbf{s}}(\mu \mathrm{M})$ \\
\hline Cephradine & 0.99 & 199.64 \\
Amoxicillin & 0.56 & 56.42 \\
Tetracycline & 0.43 & 1.49 \\
Sulfamethazine & 0.29 & 6.36 \\
Lincomycin & 0.58 & 56.46 \\
\hline
\end{tabular}

\section{Conclusion}

Radiation process was very effective for the degradation of antibiotics in aqueous solution. This study was designed to compare the figures-of-merit: chemical reaction dose constant, $d$, and kinetic parameters of the Monod equation, $k_{\max }$ and $\mathrm{K}_{\mathrm{s}}$. Mincher and Curry [24] suggested that the dose constant, $d$, is the most appropriate figure-of-merit for the majority of systems, due to its precision. However, the Monod equation model was not compared to the other figures-of-merit. The kinetic experimental results showed that the kinetic parameters of the Monod equation also represent the radiolytic decomposition of antibiotics at different concentration and are very useful to predict radiation dose requirements. The future study will include the comparison of the two different models for radiolytic decomposition of antibiotics at different concentrations.

\section{References}

[1] Diaz-Cruz, M.S., Lopez de Alda, M.J. \& Barcelo, D., Environmental behavior and analysis of veterinary and human drugs in soils, sediments and sludge. Trends Anal. Chem. 22(6), pp. 340-351, 2003.

[2] Jorgensen, S.E. \& Halling-Sorensen, B., Drugs in the environment. Chemosphere, 40, pp. 691-699, 2000.

[3] Reyes, C., Fernandez, J., Freer, J., Mondaca, M.A., Zaror, C., Malato, S. \& Mansila, H.D., Degradation and inactivation of tetracycline by $\mathrm{TiO} 2$ photocatalysis. J. Photochem. Photobiol. A; Chem., 184, pp. 141-146, 2006.

[4] Balcıoğlu, I.A. \& Ötker, M., Treatment of pharmaceutical wastewater containing antibiotics by $\mathrm{O}_{3}$ and $\mathrm{O}_{3} / \mathrm{H}_{2} \mathrm{O}_{2}$ processes. Chemosphere, 50, pp. 85-95, 2003.

[5] Bautitz, I.R. \& Noguerira, R.F.P., Degradation of tetracycline by photoFenton process-Solar irradiation and matrix effects. J. Photochem. Photobiol. A; Chem., 187, pp. 33-39, 2007.

[6] Drillia, P., Dokianakis, S.N., Fountoulakis, M.S., Kornaros, M., Stamatelatou, K. \& Lyberatos, G., On the occasional biodegradation of pharmaceuticals in the activated sludge process: The example of the antibiotic sulfamethoxazole. J. Hazard. Mater., 122, pp. 259-265, 2005. 
[7] Hernando, M.D., Mezcua, M., Fernandez-Alba, A.R. \& Barcel, D., Environmental risk assessment of pharmaceutical residues in wastewater effluents, surface waters and sediments. Talanta, 69, pp. 334-342, 2006.

[8] Brown, K.D., Kulis, J., Thomson, B., Chapman, T.H. \& Mawhinney, D.B., Occurrence of antibiotics in hospital, residential, and dairy effluent, municipal wastewater, and the Rio Grande in New Mexico. Sci. Total Environ. 366, pp. 772-783, 2006.

[9] Cabello, F.C., Heavy use of prophylactic antibiotics in aquaculture: a growing problem for human and animal health and for the environment. Environ. Microbiol., 8(7), pp. 1137-1144, 2006.

[10] Barton, M.D., Antibiotic use in animal feed and its impact on human health. Nutr. Res., 13, pp. 279-299, 2000.

[11] Ingerslev, F., Torang, L., Loke, M.L., Halling-Sorensen, B. \& Nyholm, N., Primary biodegradation of veterinary antibiotics in aerobic and anaerobic surface water simulation systems. Chemosphere, 44, pp. 865-872, 2001.

[12] Arslan-Alaton, I. \& Dogruel, S., Pre-treatment of penicillin formulation effluent by advanced oxidation processes. J. Hazard. Mater., B112, pp. 105-113, 2004.

[13] Arslan-Alaton, I. \& Gurses, F., Photo-Fenton-like and photo-Fenton-like oxidation of Procaine Penicillin G formulation effluent. J. Photochem. Photobiol. A; Chem., 165, pp. 165-175, 2004.

[14] Alaton, I.A., Dogruel, S., Baykal, E. \& Gerone, G., Combined chemical and biological oxidation of penicillin formulation effluent. J. Environ. Manage., 73, pp. 155-163, 2004.

[15] Abellan, M.N., Bayarri, B., Gimenez, J. \& Costa, J., Photocatalytic degradation of sulfamethoxazole in aqueous suspension of $\mathrm{TiO}_{2}$. Appl. Catal. B: Environ. 74, pp. 234-242, 2007.

[16] Getoff, N., Radiation-induced degradation of water pollutants-state of the art. Radiat. Phys. Chem., 47, pp. 581-593, 1996.

[17] Zhang, S.J., Jiang, H., Li, M.J., Yu, H.Q., Yin, H. \& Li, Q.R., Kinetics and mechanisms of radiolytic degradation of nitrobenzene in aqueous solutions. Environ. Sci. Technol. 41, pp. 1977-1982, 2007.

[18] Basfar, A.A., Mohamed, K.A., Al-Abduly, A.J., Al-Kuraiji, T.S. \& AlShahrani, A.A., Degradation of diazinon contaminated waters by ionizing radiation. Radiat. Phys. Chem., 76, pp. 1474-1479, 2007.

[19] Basfar, A.A., Khan, H.M., Al-Shahrani, A.A. \& Cooper, W.J., Radiation induced decomposition of methyl tert-bytyl ether in water in presence of chloroform: Kinetic modeling. Water Res., 39, pp. 2085-2095, 2005.

[20] Hsieh, L.L., Lin, Y.L. \& Wu, C.H., Degradation of MTBE in dilute aqueous solution by gamma radiolysis. Water Res., 38, pp. 3627-3633, 2004.

[21] Mucka, V., Silber, R., Pospisil, M., Camra, M. \& Bartonicek, B., Radiation degradation of polychlorinated biphenyls. Radiat. Phys. Chem., 57, pp. 489-493, 2000.

[22] Lee, B. \& Lee, M., Decomposition of 2,4,6-trinitrotoluene (TNT) by gamma irradiation. Environ. Sci. Technol., 39, pp. 9278-9285, 2005. 
[23] Yu, S., Lee, B., Lee, M., Cho, I. \& Chang, S., Decomposition and mineralization of cefaclor by ionizing radiation: Kinetics and effects of radical scavengers. Chemosphere, In press, 2008.

[24] Mincher, B.J. \& Curry, R.D., Considerations for choice of a kinetic fig. of merit in process radiation chemistry for waste treatment. Appl. Radiat. Isotopes, 52, pp. 189-193, 2000.

[25] Marx, M.-C., Wood, M. \& Jarvis, S.C., A microplate fluorimetric assay for the study of enzyme diversity in soils. Soil Biol. Biochem., 33, pp. 16331640, 2001.

[26] Kennedy, L.J., Selvi, P.K., Padmanabhan, A., Hema, K.N. \& Sekaran, G., Immobilization of polyphenol oxidase onto mesoporous activated carbons isotherm and kinetic studies. Chemosphere, 69, pp. 262-270, 2007.

[27] Chen, W.H., Chen, S.Y., Khanal, S.K. \& Sung, S., Kinetic study of biological hydrogen production by anaerobic fermentation. Int. J. Hydrogen Energy, 31, pp. 2170-2178, 2006.

[28] Sousa, H.A., Afonso, C.A.M. \& Crespo, J.G., Kinetic study of the enantioselective hydrolysis of a meso-diester using Pig Liver Esterase. $J$. Chem. Technol. Biotechnol., 75, pp. 707-714, 2000.

[29] Yu, K., DeLaune, R.D. \& Beockx, P., Direct measurement of denitrification activity in a Gulf coast freshwater marsh receiving diverted Mississippi River water. Chemosphere, 65, pp. 2449-2455, 2006.

[30] Lin, T.Y. \& Wu, C.H., Activation of hydrogen peroxide in copper(II)/amino acid/H2O2 system: effects of $\mathrm{pH}$ and copper speciation. $J$. Catal., 232, pp. 117-126, 2005. 